\title{
Alfredo Casella and L'Accademia Chigiana Senese
}

\author{
Anita Piscazzi \\ Università degli Studi “Aldo Moro” di Bari, Bari, Italy
}

\begin{abstract}
This essay analyses the cooperation between Alfredo Casella, a charismatic critic, composer, and pianist of the 20th century and the Accademia Musicale Chigiana of Siena. During this cooperation, Casella became a close collaborator and musical advisor to Count Guido Chigi Saracini, the founder and patron of the Accademia, where Casella had regularly taught piano lessons and held conducting courses ever since its foundation. Moreover, the essay will discuss the Settimana Musicale Senese festival, Casella's own brainchild, which was created in 1939 and entrusted to the artistic direction of the Turin composer. Amongst the merits of the festival there was the rediscovery and revaluation of the music of outstanding composers such as Antonio Vivaldi, Scarlatti, Pergolesi, Galuppi, Caldara, Salieri, whose production was virtually unknown at that time. Finally, the essay will analyse Casella's enormous contribution to the human arts, which he accomplished by combining musical activities with the interest and commitment to literature and plastic art. Proof of such devoted effort is the Ars Nova journal, which Casella himself established and tirelessly improved through the years.
\end{abstract}

Keywords: music academy, music festival, music and literature journal, revaluation of works and artists, arts

\section{Introduction}

A charismatic critic, composer, and pianist, Alfredo Casella and his monumental cooperation with the Accademia Musicale Chigiana of Siena have totally reshaped the Italian musical landscape. Whereas a prestigious journal such as this one will certainly provide the appropriate place to analyse Casella's project, a single essay could barely convey the full extent of Casella's enormous contribution to the Italian musical culture. Bearing this in mind, this essay will discuss the impact that Casella had on Italian music during the early decades of the 20th century, showing how his cultural background and his immense knowledge of the new trends of composition have changed the Italian musical culture forever. Moreover, the essay will also consider significant events that occurred in Paris and Vienna at that time since both cities were home to the two dominant stylistic trends in the previous century; respectively, Neo-classicism, of which Igor Stravinsky was considered the emblem and expressionism of which Arnold Schoenberg is the epitome. ${ }^{1}$

Alfredo Casella, who was born in Turin in 1883 and died in Rome in 1947, was a composer, a pianist, a conductor, an author, and an organizer of events aimed at the promotion of contemporary music. Throughout his life, he contributed enormously to cultural information, shaking the 19th-century musical tradition to its core. In the process, he promoted the works of major European composers and revolutionised the way of living of

Anita Piscazzi, Ph.D., Psicologia, Formazione e Comunicazione, Università degli Studi “Aldo Moro" di Bari.

1 Cf. Salvetti, G. (2013). La nascita del Novecento (p. 98). Torino: EDT. 
younger generations, bringing them to a level of maturity and cultural emancipation that had hitherto been unimaginable. As an organizer of events, Casella's initiatives brought about the means of information where they were absent as he strived to support them against opponents of all kinds. In the early 20th century, Italy continued to be the birthplace of opera which was regarded as the only typically Italian form of art destined to carry on the splendour of the previous century. Names such as Rossini, Bellini, Donizetti, and Verdi were soon joined by three equally popular names, Puccini, Mascagni, and Giordano whose artistic production became pivotal in the Italian musical culture. In fact, opera seasons were regularly held and attended in many cities while instrumental concerts were instead limited to cities where orchestras were available such as Turin, Milan, Rome, Florence, Parma, Naples, Palermo, and chamber concerts were the preserve of the educated elite who preferred traditional programs and scorned any sort of musical innovation.

\section{Casella's Innovative Project and the Establishment of New Musical Societies}

While Alfredo Casella's initiatives radically changed the Italian musical culture by first elevating it from its melodrama-anchored provincialism and then by rejuvenating it, his methods were nonetheless influenced by the instrumental music of the 18th century, a time during which Italy ranked first in the European musical scene. He carried out his project through the dissemination of contemporary music by foreign authors who were already well-established in the musical circles of Paris, Vienna, and Berlin, trying to employ a typically Italian language that could be adjusted to modern times without losing its defining features. The attempt to revive the use of musical instruments in Italy had already had precursors such as Martucci, Sgambati and others, who, however, had not had much success as they had found themselves living in a period when the opera genre flourished. Conversely, Casella initiated his project when the melodrama was already beginning its decline. At that time, it was possible to feel the pressure against a genre that in the year 1900 only Puccini managed to immortalize, and, therefore, people were already seeking new musical horizons that would encourage and inspire young composers. The problem about the instruments was the most pressing one for the new generations of musicians. Casella could address it better than any of his contemporaries as a result of his radically different cultural background. In fact, having lived in Paris for nearly 20 years, in a culturally fertile and thoroughly stimulating period, Casella personally experienced remarkable events in music, such as the advent of Impressionism, the legendary performances of Diaghilev's Russian ballets, the first performance of Stravinsky's Rite of Spring and Schoenberg's Pierrot Lunaire. ${ }^{2}$ While in Paris, he managed to strike up a friendship with famous composers, musicians, and writers such as Debussy, Ravel, Enesco, Rimsky-Korsakov, Dukas, Stravinsky, De Falla, Mahler, Cortot, Casals, Thibaut, Ysaie, Saint-Saens, Proust, Daudet, Zola, and Cocteau.

Having enriched his experience in France, he returned to Italy in 1915 and was immediately considered a catalyst for change, a champion of the new music, a reformer and, despite the inevitable disagreements, he soon obtained a number of followers. His versatility was crucial towards his project, for it allowed him to stand out from his fellow musicians and to give a meaning to his many activities (such as that of performer, director of classical and contemporary music, composer, arranger, and editor of baroque, classical and romantic masterpieces), allowing him to produce countless writings and to establish major institutions, some of which are

${ }^{2}$ Cf. Restagno, E. (Ed.). (1983). Petrassi (p. 39). Torino: EDT. 
still active today. His first major work in the most qualified Italian musical circles was Italian Rhapsody for orchestra which he composed at the age of 26. This work marked Casella's first serious attempt to create a national style that was instrumental and modern at the same time, thus achieving a goal equally shared by plenty of young European composers. Accordingly, the most striking example was the Spanish composer Manuel De Falla who, upon completing his education in Paris, returned to his country where he committed himself to the revival of the Iberian folk music, obtaining much success in his project. It was, in fact, commonplace for many composers to appeal to the national folk music as it gave them a possibility to create new academies. Musicians such as Bartok, Smetana, Sibelius, Grieg, just to name a few, had all developed their own style by drawing upon their national folk music. In Berlin in 1912, Schoenberg performed Pierrot Lunaire for the first time, and subsequently performed it again in Paris, obtaining stardom at European level. Owing to his performance, Schoenberg's fame grew exponentially and his revolutionary style influenced virtually every major contemporary musician, including even individually-oriented composers such as Maurice Ravel and Igor Stravinsky. However, such influence was far from being radical in Stravinsky, for his musical nature led him toward classicism and diatonicism; thus, Stravinsky and Schoenberg remained distinct from each other, each creating his own school that provided two alternatives for many emerging artists.

The representation of the Rite of Spring by Stravinsky in Paris in 1913, which marked the end of the evanescent music typical of Debussy's period, brought music to a solidity of construction and rendered it architecturally essential so that the atonal speech conveyed an everlasting latent sense of secrecy. These features were those that Casella owed to the Russian composer as they became the basis of a style and a form that he felt to be his own. However, having made plenty of experiments, it was not until 1918 that Casella finally realised that the twelve-tone theory was far from his spirit, which was well rooted in the sense of tonality. Having officially concluded his Parisian spell in 1915, Casella returned to Italy that year and landed a teaching job at the Liceo Musicale di Santa Cecilia in Rome. The wealth of knowledge and cultural experiences gained in all areas of the musical world was such that no one else in Italy, at that time, could be compared to him. Another defining factor was the nationalistic spirit that had always bound him to his homeland and had preserved him from becoming totally absorbed in the French culture; a common pitfall for those who are exposed to a different culture for so long. However, his time in Rome, after a first idyllic year, was not shorn of the occasional controversies and heated debates; nonetheless, Casella never stooped to compromise but, rather, steadfastly pursued his mission as the leader of the contemporary music culture. It was during those two years in Rome that he produced some of his most beautiful piano compositions, namely, Pagine di Guerra for the four-hand piano and Sonatina Op.28. During 1916, another side of his versatility came to the fore as both creator and organizer of musical societies aimed at promoting the music by the best emerging Italian and foreign composers. A similar society had already been thriving in France, and Casella had been part of since its foundation. In his own words:

One of the immediate objectives that I was determined to achieve was to provide Italy with a society which would act as a "Trojan horse" in the middle of an absurdly backwater, provincial environment. And I decided to name it the "National Society of Music", similar to the French one, whose enormous contributions to the musical history of that country I've already praised. Another society by the same name had been established the year before in Spain by Manuel De Falla, who, aided by the best young Iberian composers, gave birth to a truly noble activity. I myself was supported by other young teachers who were equally motivated by that burning desire to join the fight against amateurism, mediocrity and provincialism that swamped Italy at the time. These companions of the first adventure were Ottorino Respighi, 
Pizzetti, Malipiero, Perinello Carlo, Vittorio Gui and Vincenzo Tommasini. Having initially only shared mere fraternal talks, our contacts later evolved into regular meetings held in the beautiful palace of Senator Tommasini on Via Nazionale. During those meetings, our project started gradually to take the shape of the institution that we wanted to establish in defence of the then emerging Italian music, and, just as I had always wished, we called the institution (in the likeness of ideals and purposes of its French counterpart) the "National Society of Music". This association arose with the purpose of performing the most interesting music of the Italian youth, thus revising what we had forgotten, printing the most relevant new national compositions, publishing regular journals, and, finally, setting up a system of music exchange with major foreign countries. ${ }^{3}$

The realisation of such an ambitious project certainly involved a great deal of courage but also a lot of faith in Casella's ideas. The project successfully overcame endless obstacles through the painstaking support a few loyal friends. During the first series of concerts, which began on March 16, 1917, over 112 compositions were performed, 102 of which by Italian composers. This was an unprecedented event for its time, sparking, in turn, bitter criticism, controversy, and fierce opposition. The performances were constantly jeered at and frequently accompanied by scoffing shouts and mocking whistles. This shows exactly the level of cultural backwardness in which Casella was pursuing his project. Although in 1918 the achievements of the National Society of Music were satisfactory, Casella and his associates decided to rename it the Italian Society of Modern Music (S.I.M.M.) as a way to clear up any misunderstanding surrounding the purpose of the institution. The elected president of S.I.M.M. was Count Enrico San Martino Valperga, a senator of the Kingdom of Italy and the president of the Accademia of Santa Cecilia while the secretary general was Alfredo Casella, who was unarguably the embodiment of the society itself. During that year, compositions by foreign authors abounded, but this only embittered the already harsh criticism towards the Piedmontese composer and his associates. However, the fruits of Casella's hard work were finally, even if slowly, beginning to ripen. His courageous facticity, since then supported by a few faithful friends, ended up appealing to a large number of young people who were taking their first steps in the musical world.

The number of Casella's followers and collaborators started to grow exponentially, and contemporary music was finally beginning to gain a foothold in Italy. At the same time Casella decided to resume his activities abroad as a means to promote the new Italian music. However, whereas his double role as a pianist-composer took him on numerous tours across both Europe and the United States, his resuming such activity marked also the beginning of the downfall of the Italian Society of Modern Music because no one else could run it with as much passion and skill. In 1923, having consulted the composer Gian Francesco Malipiero, the only remaining friend from the early years who still shared his ideals, he came up with the idea of establishing a new organisation of modern musical culture, similar to that founded the year before in Salzburg by some European composers as the Italian Society of Contemporary Music (S.I.M.C.). The SIMC aimed at promoting in Italy every musical experience that existed at that time and at drawing new generations of musicians towards the European musical landscape. However, it was his chance meeting with the poet Gabriele D'Annunzio that allowed his project to materialize through the birth of the Corporation of the New Music (C.D.N.M.) which was later merged into the Italian section of the S.I.M.C.. The activities of this new organisation contributed a great deal to the diffusion of contemporary musical production. It was at that time that the pianists Bela Bartok and Hindemith with his quartet

\footnotetext{
3 Casella, A. (1941). I segreti della giara (p. 123). Sansoni, Firenze.
} 
arrived in Italy along with Schoenberg who directed his Pierrot Lunaire in a series of eight concerts, leaving an indelible mark in all cities where he performed, aside from Rome where he had poor reception. Such acclaim was a sign that the times were about to change. Equally favourable reception had the most significant works of the greatest European composers during the five-year period of activity of the C.D.N.M (later merged into the S.I.M.C.). On the heels of this success, three festivals of contemporary music were subsequently held in Venice, Florence, and Siena. The success of the 1925 Venice Festival brought about Casella's decision to hold the festival annually, an event which sparked immediate international interest and which has been hosted to this very day.

\section{Casella and the Accademia Musical Chigiana}

In 1932, Casella met Count Guido Chigi Saracini, a patron and the scion of a wealthy, noble family. A music enthusiast, Count Saracini founded the Accademia Musicale Chigiana, investing in this venture his own material goods by providing world-class musicians with the magnificent palace on Via di Città. ${ }^{4}$ Underlying such generous decision was the Count's immense passion for music which he developed during his educational years at the Luigi Cherubini Conservatory in Florence. Thus, having inherited a considerable fortune, the Count immediately took to promoting the musical activity in his city. Such generous donation led to the creation of the Senese Quintet, which was financially backed by Saracini, who also organized concerts with the intent of donating all profits to charity. Among the events organised by Count Saracini stands out the 1913 performance of Giuseppe Verdi's Requiem Mass at the Church of San Francesco. The event had resonance nationwide, owing to the charismatic personality of the interpreters (the director was Edoardo Mascheroni, one of Verdi's favourite musicians), the relative rarity of the piece, and the crucial presence in Siena of Arrigo Boito, a close friend of Saracini's who also influenced the count's future activities. At the end of World War I, to which Saracini had participated as a volunteer in the Italian army, the Count initiated a restructuring program of his palace to make it even more suitable to the needs of music. Thus, he employed the Senese painter, sculptor, and architect Arturo Viligiardi who turned what had once been the ballroom into a well-equipped concert hall. The concert hall was solemnly inaugurated on November 22nd, 1923 with the first event of a season which the Count entitled Micat in Summit, a title inspired by an inscription on his family crest. ${ }^{5}$ In 1939, following Alfredo Casella's advice, who had been teaching piano and directing the orchestra ever since the academy was founded and who had also been working in Siena since 1928, the count created the VI Festival of the International Society of Contemporary Music. However, by 1932, he had already established those crucial completion courses that would make the Accademia Chigiana world famous. In 1939, he created the Settimana Musicale Senese festival entrusting its artistic direction to Alfredo Casella. This festival was credited with promoting the rediscovery Antonio Vivaldi's music, a composer, whose production was at that time pretty unknown. In the wake of such enthusiasm, subsequent editions of the Settimana were characterized by a search for obsolete or little known events in music history with exhumations of other composers, especially Italian ones, such as Scarlatti, Pergolesi, Galuppi, Caldara, Salieri, and the revaluation of the works of lesser known or unknown musicians who had nonetheless been famous in their own days. Therefore, it is because of the intense partnership between Casella and the

\footnotetext{
${ }^{4}$ Cf. Burchi, G., \& Catoni, G. (2008). La Chigiana di Siena. Guido Chigi Saracini e la sua Accademia musicale (p. 278). Siena: Fondazione Monte dei Paschi di Siena.

5 Ibidem, p. 280.
} 
Accademia Chigiana and Saracini's patronage that the Settimana Musicale Senese festival still exists today and perpetuates the spirit of raising awareness and diffusing the masterpieces of the Italian musical heritage. In addition to lavishing his material goods and to renovating and adapting his magnificent palace, the founder managed to hire many world-class musicians, appointing them as teachers to the various courses taught at the academy. The success of the academy was immediately recognised and the fame of the Chigiana rapidly spread everywhere, making Siena the favoured destination for scores of aspiring young musicians from all over the world. It would be beneficial to mention that some of the alumni of the Academia went on to make a name for themselves in the international scene, to name but a few: Carlo Maria Giulini, Zubin Mehta, Daniel Oren, Roman Vlad, Claudio Abbado, Salvatore Accardo, Uto Ughi, Daniel Barenboim, Alirio Diaz, Joaquin Achucarro. Aside from organising the courses, Count Chigi Saracini started a live season of winter concerts in 1923 called Micat in Summit, which has been hosted ever since then. In 1961, the Accademia Musicale Chigiana became a Foundation after the Count bequeathed all his assets in favour of the Academia. Owing to the Count's bequest and to generous gifts from various institutions such as the Fondazione Monte dei Paschi di Siena, the academy has thrived ever since then, perpetuating the ideals of Casella and his associates.

\section{Ars Nova: Music, Literature, and Art}

It should be mentioned that Casella was a quintessential humanist capable of combining the musical activity with the interest and commitment to literature and plastic art. Evidence for this is his work for the Ars Nova journal, which he himself founded and tirelessly redesigned through the years. Casella returned permanently to Rome in 1915, the year when Italy became embroiled in World War I. After spending a long period of training and apprenticeship in Paris, Casella continued his effort to support the modern Italian musical trends which he had already started while in France. During its first year, the S.I.M.M. already counted over a hundred members including major contemporary Italian composers, such as Malipiero, Respighi, Pizzetti, Gui, Tommasini, but also musicians younger than Casella who nonetheless shared his ideals, and even members of the previous generation who certainly had a much more conservative orientation such as Zandonai, Alaleona, Pick, Mangiagalli, Gnecchi). The S.I.M.M proposed to promote the art of renewal and research of the Italian musical spirit, encouraging in every way the production and performance of musical compositions that were attractive in terms of originality, boldness, innovation. ${ }^{6}$ Thus, in July 1917, Ars Nova became the S.I.M.M.'s official journal and its very first issue came out that year. Comprising eight pages divided in two columns, this first issue summarized the dense and yet so short history of the society, describing its activities and outlining its upcoming projects. The stated aim was to provide both a "source of information, culture and propaganda" and to give people "a way to criticise and defend their ideas". ${ }^{7}$ However, this project did not come about until December 1st, 1917, when Ars Nova was redesigned with a structure destined to remain largely unchanged: a few broad articles comprising reviews of selected music and concerts, accompanied by some sections which were mostly characterized by aphoristic tag lines and witty and pungent remarks, such as: "Thoughts, aphorisms, paradoxes, etc... etc."; "Ariettes oubliées..."; "Authentic news", "Nonsense, nonsense enormity, etc... etc."; and details relating to the

\footnotetext{
6 Messina, M. G. (2003). Tra pittura e musica. Da "Ars nova” a "Valori plastici” e ritorno. In Alfredo Casella e l'Europa (pp. 249-274), atti del Convegno internazionale di studi (Siena, June 7-9, 2001), Mila De Santis (Ed.), Olschki, Firenze.

7 Casella, A. (1917). Fede di nascita... Ars nova, I(1), 8.
} 
activity of the society. The second issue, which came out the following year, featured the first header of the journal, which was designed by the Roman photographer Gustavo Bonaventura. From the fifth issue of that year onwards, the journal was enriched with pictures, mostly reproductions of paintings by contemporary artists. Alas, partly owing to the difficulties of finding primary sources during and immediately after the first world conflict, and owing to the lack of financial support which came almost exclusively from membership fees, the idea of a regular monthly publication was gradually abandoned. The first issue of the third year (dated November 1st, 1918) coincided with a partial structural reorganization of the journal. Thus, Casella formally became the general editor making the journal available to non-members for the first time, and extending it to 16 pages, as opposed to the previous 8 and 12 pages. However, such far-looking plan was in fact quite short-lived. As a court order officially disbanded the society between February and March 1919, Ars Nova also ceased to exist. While crucial was the nagging problem pertaining to financial support (up until the very last issue, the journal had declared its lack of affiliation to any profit-making corporation, choosing freedom as its main distinctive feature), the irregularity of the outputs was also caused by "the impromptu editorial staff, headed by contributions solicited from time to time, which lacked sources to draw upon and without far-reaching programs". ${ }^{8}$ While the circumstances of war might seem a natural obstacle to the launch of initiatives pertaining to the arts, Casella made his claims especially for those who were not fighting at the front but who still stood for "the evolutionary force of the country, its chances of progress, its future as a magnificent nation". ${ }^{9}$ Thus, he felt he had a duty to take action so that "the Italian people were kept coldly quiet in their civil life as well as in their higher spiritual functions" ${ }^{\prime 10}$. Such conviction underlay his decision to give the journal the appearance of a paper that was militant, anti-academic, and compliant to current events and with plenty of pungent slogans such as: "The imbeciles, the eavesdroppers, the pests do not belong with S.I.M-M.", or "those who deem our journal boring should contact the editor immediately". ${ }^{11}$ By virtue of that, significant theoretical essays were complemented by sidebars of biting irony, often published under pseudonyms, which mercilessly attacked the conservatism of the critics as well as that of the public as a whole, denouncing also the incompetence of contemporary journalism. This purpose fit quite well with the standards of avant-garde literary journals such as the Florentine Lacerba (initially edited by Giovanni Papini and Soffici), similar to Ars Nova in terms of its graphic setting and of its use of caustic and witty remarks. ${ }^{12}$

Casella and his associates waged a large war at their own home front. First and foremost, he felt a compelling urge to restore the full dignity of the Italian music as a form of art of its own, which had been lost when music came to be identified as a sort of popular entertainment (in the form of melodrama, living room romances, popular song, etc.), as a result of entrusting mere amateurs and the market with the collective aesthetic orientation. Such desire originated from the dialogue and the sharing of objectives with "sister" disciplines which informed the interdisciplinary approach of his journal. In this respect, Casella sought and obtained the cooperation of Papini, which in November 1917 had stated:

\footnotetext{
8 Messina, M. G. Tra pittura e musica. Da "Ars nova" a "Valori plastici" e ritorno. In Alfredo Casella e l'Europa, op. cit., p. 276.

9 Casella, A. Fede di nascita ... op. cit., p. 10.

10 Ibidem, pp. 11-13.

11 Ibidem, p. 15.

12 Cf. Nicolodi, F. (1998). Aspects compositionnels et esthetiques du néoclassicisme en Italie. In V. H. Danuser (Ed.), Die Klassizistische Moderne in der Musik des 20. Jahrhunderts (pp. 73-91). Schott, Mainz.
} 
I will create a journal of art where music covers two-thirds of the journal and the remaining one-third will be devoted to literature and the plastic arts. I intend to underline the links between all these new arts as they are becoming closer and closer to one another today more than ever before. ${ }^{13}$

However, Papini's contribution was only limited to his signature article published in the second issue of the journal, Posto anche all'arte! (Give Art its Own Space!) (II, 2, pp. 1-2) and, despite all the best intentions, little space was actually devoted to literary issues. Conversely, a much more significant contribution to Ars Nova was provided by artists and critics who adhered to the new figurative movements. Some of them were involved with futurist movements, such as Mario Recchi who contributed with Anti-naturalism (II, 3, pp. 4-5 and 6, pp. 4-5) and Lineamenti di Storia dell'arte contemporanea (Outlines of the History of Contemporary Art) (III, 3, pp. 8-10); others contributed to the metaphysical section about the "plastic values", in particular, Mario Broglio who published Teatro Plastico (Plastic Theatre) (II, 5, pp. 5-7); Carlo Carra with Contributo ad una nuova critica (Contributing to a New Critique) (III, 1, pp. 6-9) and Conti che si chiudono (Settling the score) (III, 4-5, pp.7-8); and Giorgio De Chirico with Guillaume Apollinaire (III, 2, pp. 7-8), Arte metafisica e scienze occulte (Metaphysical art and Occultism) (III, 3, pp. 3-4), the latter published along En attendant la victoire. Article dans l'evolution an inedited contribution by the French Cubist painter Albert Gleizes (III, 4-5, pp.17-22). Additionally, there are four contributions by Alberto Savinio who, having dismissed his role as avant-garde composer and "pianoclast" typical of his youth spent in Monaco and Paris, embraced the prose style and found Ars Nova to be a perfect writing workshop. In this respect, Savinio intended to change the role played by critique. He wanted critique to become the catalyst, rather than the nodding spectator, for that much awaited participation of the music in the race towards modernity. ${ }^{14}$ More strictly musical contributions were instead penned by Gian Francesco Malipiero, the closest and most loyal ally of Casella in the modernist battle; Ferruccio Busoni, who published in two issues, respectively, Cenni di una nuova estetica musicale (Notes on New Musical Aesthetics), and the Italian adaptation of Entwurfeiner der neues Aesthetik Tonkunst which he had already published in the Rome-based journal Harmonia in 1913; by the librarian and musicologist Luigi Torri; by the polygraph Sebastiano Arturo Luciani, who published a review about Edward Gordon Craig's theatre; by the young critic Guido M. Gatti, who had had an incisive, though rather brief, experience as editor in chief of the Riforma Musicale journal, who contributed to Ars Nova with a review on the methods of teaching music in conservatories and another review about Chabrier and Satie, two eccentric contemporary French composers. However, it may come as no surprise that the most relevant contributions to the journal came from abroad, and from France in particular. Amongst the most significant foreign contributors, there were Henry Prunières, who was fond of Jeune musique italienne; Jean d'Udine (nom de plume of Albert Cozanet); Jean Louis and Marnold Laloy, the latter contributing with an article about Chinese music; and the Russian-born student Joel Engel who wrote about Jewish music. Nonetheless, it was indeed Alfredo Casella who authored the largest number of contributions, ranging from illustrations of the features of the new Italian music to the analysis of the distinctive music of Impressionism; from a touching tribute to the memory of Claude Debussy, who passed away on March 26th, 1918, to his reflections on the essence of art and modern music; from the heated debate with Pizzetti about the future possibilities of musical theatre, which, according to Casella lay solely within the interaction between

13 Petrocchi, F. (1992). Le ragioni dell'arte: musica, pittura e letteratura. In “Ars nova” 1917-1919, ESI, Napoli, p. 12.

14 Cf. Storti, R. (1995). Il polemista melomane dell" "Ars nova”." "Ariel”, X, 1-2, pp. 305-310. 
music, painting and gesture, as there were no more realistic future possibilities for a combination between music and speech, to his distancing himself from musical futurism.

\section{Conclusion}

It would be inaccurate to claim that Casella stood completely aloof from musical futurism as he appeared to have been influenced by it, even though remotely. In this respect, one might think about the trenchant radicalism typical of Ars Nova, which was expressly declared through the intent of casting out the 19th century theatricals of the post-Rossini period, including even the national idol Giuseppe Verdi (certainly not as the author of the beloved Falstaff, but, rather, as the composer of the popular overtures of Nabucco and the Sicilian Vespers, or as the misunderstood proponent of a "return to the past"). From its very inception, however, Ars Nova had been proudly independent of any movement and educational framework. Evidence for this was the opposition to those exacerbated nationalist thrusts, even more significant given the climate of war in which the journal was created, and the demand for a total aesthetical autonomy of the musical art, a "science of the sound" that "does not obey other laws other than those underlying the relationship between the sounds and is accountable only to the principles of beauty and novelty". ${ }^{15}$ At a safe distance from the vanguard influences, Casella tested his instruments and his theoretical apparatus in a neoclassical workshop, bringing together passionate musicians, or, to quote Soffici: "he assembled and reassembled the scattered pieces of beauty with the purpose of reshaping a great ideal figure". ${ }^{16}$ If the typically Italian musical qualities cannot be reduced to simple melody, as they encompass grandiosity, severity, robustness, compactness, simplicity of lines, plastic and architectural fullness, balance, vitality, courage and that tireless pursuit of novelty, the new course of national music can only be identified with a sort of classicism, which complements in a harmonious eurhythmy all the latest innovations both Italian and from abroad, while, at the same time, differing a great deal from French Impressionism, from Strauss' decadence, from Stravinsky's primitive, from Schoenberg's cold scientism, from Iberian sensuality, and from the audacity of the last Hungarian fantasy. ${ }^{17}$ For this reason even when the Ars Nova project came to an end, its legacy has lived on through the era of the new Italian classicism.

\section{References}

Restagno, E. (Ed.). (1983). Petrassi. Torino: EDT.

Burchi, G., \& Catoni, G. (2008). La Chigiana di Siena. Guido Chigi Saracini e la sua Accademia musicale (The Chiagiana academy of Siena. Guido Chigi Saracini and his music academy ). Siena: Fondazione Monte dei Paschi di Siena.

Casella, A. (1917). Fede di nascita... (Birth certificate...). Ars Nova, I(1).

Casella, A. (1941). I segreti della giara (The secrets of the Jar). Firenze: Sansoni.

Casella, A. (1918). Le musiche nuove all'Augusteo (The new music at the Augusteo). Ars Nova, II(3), 1-3.

Messina, M. G. (2003). Tra pittura e musica. Da "Ars nova" a "Valori plastici" e ritorno (Between painting and music. From "Ars Nova" to "Plastic values"). In Alfredo Casella e l'Europa, atti del Convegno internazionale di studi (Siena, 7-9 giugno, 2001), a cura di Mila De Santis, Olschki, Firenze.

Nicolodi, F. (1998). Aspects compositionnels et esthetiques du néoclassicisme en Italie (Compositional and aesthetical aspects about the Italian neoclassicism). In V. H. Danuser (Ed.), Die Klassizistische Moderne in der Musik des 20. Jahrhunderts. (Classicist modernism in 20th century music). Mainz: Schott.

\footnotetext{
15 Casella, A. Le musiche nuove all'Augusteo. Ars nova, II(3), 1-3.

16 Ibidem, pp. 2-4.

17 Ibidem.
} 
Petrocchi, F. (1992). Le ragioni dell'arte: musica, pittura e letteratura (The elements of the art: Music, painting and literature). In “Ars Nova” 1917-1919. Napoli: ESI.

Salvetti, G. (2013). La nascita del Novecento (The onset of the twentieth century). Torino: EDT.

Storti, R. (1995). Il polemista melomane dell' "Ars Nova” (The music-loving critic of “Ars Nova”). “Ariel”, X, 1-2. 